\title{
MECARÕ, AMAZONIA IN THE PETITGAS COLLECTION
}

\section{Leonor Veiga Universidade de Lisboa}

The exhibition Mecarõ, Amazonia in the Petitgas Collection should have run in MO.CO. Hôtel des Collections (HC) in Montpellier, France, from March 3, 2020 to May 31, 2020. As the coronavirus pandemic altered the programing of the institution, Mecarõ ran through September $30,2020 .^{1}$

Having seen at the $\mathrm{HC}$ the exhibition concerning the minimalism masterpieces of the collection of Japanese entrepreneur Yasuharu Ishikawa, I was drawn to Mecarõ for several reasons: 1) I am Brazilian, and the Amazon remains a fascinating subject to me; 2) at the time of my first visit on June 25, 2020, I was actively working as cocurator for a women-only show Biennale in which the theme is Natura, the Latin word for nature; 3 ) among the artists that I showcase in the exhibition is Gabriela Noujaim, an artist from Brazil who chose to contribute to Natura with an artwork that touches upon the subject of the Amazon, especially the Guardians of the Forest and the demarcation of the land of the Fox Sun Sierra, in Brazil. ${ }^{2}$

Because I thoroughly enjoyed the show, I decided to write a review for this specific dossier, "Art and the Amazon". As a researcher on the subject of collections, and more precisely on the activity of the individual collector - but with a regard on other geographies - the project that French essayist and curator Nicholas Bourriaud - who serves Montpellier Contemporain as Chief Executive Officer of MO.CO - interests me particularly. Bourriaud's project and vision has brought to this city in Southern France a cosmopolitan dimension that $\mathrm{I}$ believe is creating a growing interest in contemporary art of the highest standard among the city's population. His vision encompasses three main premises, that together create a new ecosystem for the arts: the Faculty of Fine Arts, the Cultural Center of the Panacée and the Hôtel des Collections. ${ }^{3}$ This way, it hopes to serve current and future generations, who will enjoy a new, more 'hands-on' way of learning and being in contact with contemporary art.

\section{THE COLLECTOR, CATHERINE PETITGAS: "A COLLECTOR IS AN ARTIST WITH FOUR WALLS"4}

To write this review, I went to the exhibition twice, the second time on September 6, 2020. In regard to the collector, what I could apprehend in the first time was different from what I could retrieve from the second visit. At first, it was evident that, while I am not a specialist on Latin American art like Petitgas, the list of names was of the highest standard. It comprised various world-renowned artists from Brazil, that I knew of, namely Hélio Oiticica, Lygia Clark, Ivan Serpa and Paulo Nazaré. Equally, I could sense the "underlying tension" that she suggests in the interview to Anna Kerekes, Senior Curator at MO.CO, as a strong component of her collection. ${ }^{5}$ Petitgas affirms that while the works she chooses may at first "seem attractive at first sight, [they] contain a deeper critical and political message."6

Catherine Petitgas's collection of Latin American art is one of, if not, the most important collection of art from this region by a woman collector. Petitgas admits giving priority to women, not because of a gender bias, "but [rather] because I am more touched by their work." "This aspect of her collection and her interest in "the sublimation of the banal", she says, are the two underlying features of her entire collection that, she hopes, make the collection a "coherent whole". ${ }^{8}$

Petitgas is a collector since 2000. Having grown up in North Africa, she admits she was drawn into collecting the art of Latin America because it recalled her upbringings. ${ }^{9}$ Her decision to collect art from this region led her to study Art History and allowed her to fairly quickly join groups of collectors who shared equal interests. ${ }^{10}$ Also, being the member of the Tate Gallery Latin America Acquisitions Committee (Tate LAAC) since 2002 and the Latin American Circle of the Guggenheim in New York, has given her much substrata that she then uses to acquire new works. ${ }^{11}$ In addition, 
she frequently attends art fairs and meets artists. She says: "meeting the artists and being able to have interesting exchanges with them is the very essence of my collection."12

Petitgas's interest in Latin America, of which the Amazon collection, "unveiled for the first time in its institutional scale" in MO.CO is a substantial part, $^{13}$ reflects a global movement that, in reinterpreting modernity, has permitted the inclusion of what once were "peripheral scenes that were excluded arbitrarily" from institutional discourses. ${ }^{14}$ The Amazon theme is a more recent interest of Petitgas, and one that has inspired her to foresee herself curating one day. ${ }^{15}$ The Amazon basin represents almost $40 \%$ of the total land of South America, distributed unevenly between 9 nations, all incorporated in this show. ${ }^{16}$

Petitgas's collection importance is renowned; another important show, ArtParis2019, also comprised works from this collection. Similarly, a recent individual exhibition of Ivan Serpa in London featured her collection. This demonstrates the elasticity of her acquisitions - one that allows her collection to navigate institutions and create "links between artists of a same generation, between one generation and another, or between one country and another."17 Petitgas suggests that her act of collecting is intertwined with her life; she lives surrounded by her collection and enjoys showing it in the form of small intimate exhibitions that reveal her collecting journey. This is why she paraphrases Marcel Duchamp, who said that "A collector is an artist with four walls." ${ }^{18}$

\section{THE EXHIBITION AT MO.CO.}

The exhibition is divided into four sections: "Historic Context", comprising geometric abstraction especially that of the neo-concretism; "Rottenness and Rebirth: Urban Mutations", an ensemble that evokes a return to natural (re)sources; "Amazonian Cosmology", which accentuates ethnic and social inequalities including deforestation through fires and massive cut, and equally refers to human rights violations, especially those of ethnic minorities; and finally "Tropical Feminism", a group of works that regards the forest through a feminine lens. The result is a collection of 120 works, which can be divided in three parts: those that refer to global concerns, those that mention sensibilities acquainted with those from other parts of the world and finally those that describe regional and local understanding of life.

As Brazilian independent curator and art critic Kiki Mazzucchelli describes, "the Amazon has been historically portrayed both as an untouched, mysterious territory and a land filled with innumerable riches for commercial exploitation that has attracted travellers and explorers since the $16^{\text {th }}$ century." 19 The accounts on the Amazon since the 1500 s are marked by an European bias: a narrative based on ideas of conquest of the vast wilderness. Yet, as Mazzucchelli points, "the region was already inhabited by several highly populated hierarchical societies who had created monumental earthworks - known as "geoglyphs" - that are believed to have served as ceremonial sites. $^{20}$ In recent years, the Amazon has been at the center of the worlds' debates, especially since its massive fires in 2019. And, as Bourriaud points, "the Amazon basis is now a key battlefield for the future of the planet; A slow-motion genocide, an ecological disaster, the extinction of countless animal species: Amazon has become the centre of the world, because it is there that much of our future will be decided."21 This global socio-political context makes the exhibition both topical and necessary. Despite European colonization's division between nature and culture that objectified the Amazon, nature is resilient, and regeneration has continued. The problem we face today is that collectively humanity is reaching several 'tipping points', that may signify the end of this inherent ecosystems' capacity to regenerate. This exhibition proposes to change these accounts, by demonstrating how post-1950s artists from Latin America have contributed with "individual perspectives that touch upon the social and political relationships of hundreds of ethnic groups, nine nation-states, and several national and international interest groups."22 [Fig. 1]

While the Amazon remains exoticized in most discourses, it is and has been a source of inspiration for all humankind. In 1992, Thai artist Montien Boonma was at its basin as a participant of "Arte Amazonas, an international workshop for artists in Brazil."23 In 2020, as advanced, Noujaim produced a polyptych about the subject of the Fox Sun Sierra in silkscreen on paper. This interval demonstrates that the Amazon is explored artistically by local artists as well as artists from overseas. The 


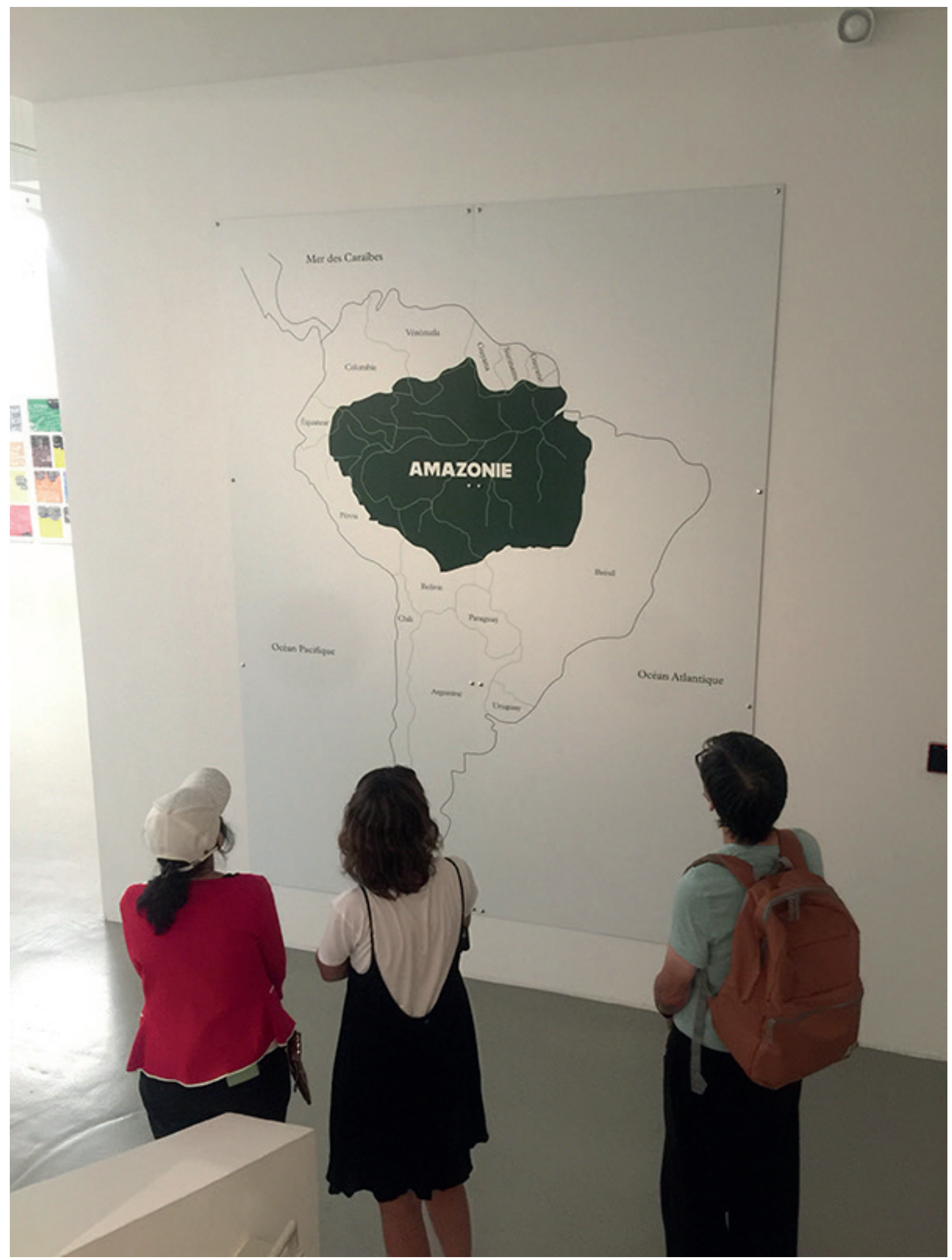

Figure 1 - The Amazon, and its scale within South America. 


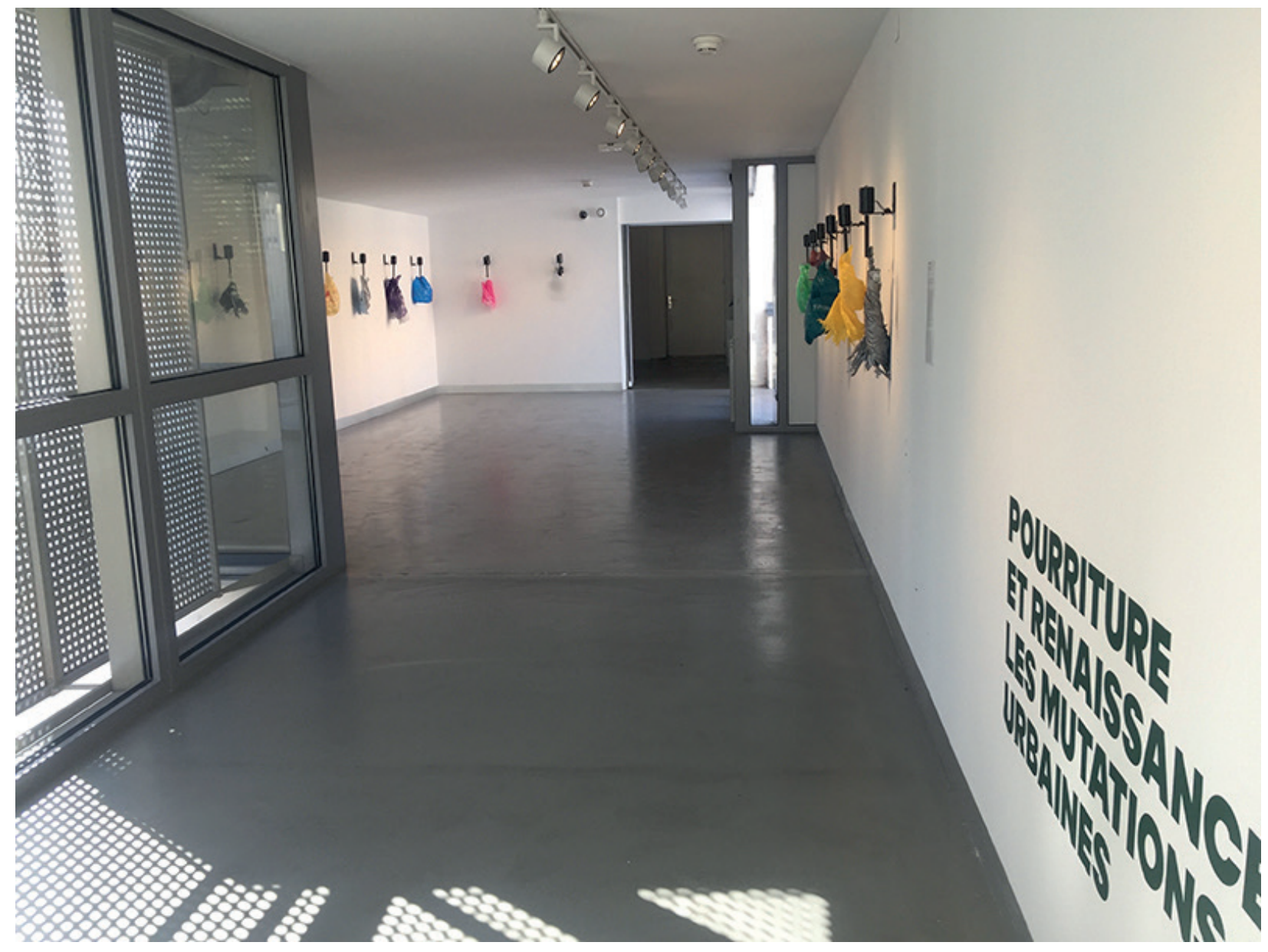

Figure 2 - Chelpa Ferro, Jungle Jam (2010).

exhibition that this text aims to review, Mecarõ, is rich in cross-cultural encounters; it comprises 47 artists - one of which from Southeast Asia, the Vietnamese Danh Vo.

Referring to the global catastrophe that the destruction of vast areas of land in the Amazon, is a poignant work by the Chelpa Ferro group. The installation Jungle Jam (2010) is comprised by several colorful plastic bags originating in Brazilian shops, suspended by motorized blenders. By showing how urgent it is to understand the difficulty in destroying a single plastic bag, it constitutes an act of social agency. This omnipresent symbol of contemporary life is responsible for much of the deterioration of fragile ecosystems, including rainforests and coral reefs. The blenders provide each person a unique experience of color, sound, and movement by means of an algorithm. ${ }^{24}$ [Fig. 2] Another work about environmental degradation is by Colombian artist Oswaldo Maciá's The Opera of Cross-Pollination (2018). This work, the first in the exhibition, constitutes a sound piece within a yellow room - a color that conveys the sun and the human solar plexus - but before, he or she must put feet protection on his or her shoes. This aspect becomes part of the experience, especially during COVID-19 times, in which much humanity wears facial masks. The installation, comprised of multiple sounds of insects that pollinize plants - an important aspect of crops maintenance -, expects to reduce the importance of sight for museum visitors while bringing to the fore the value of sound.

There are several works that contain a global stance, but through traditional material manifestations that are equally found in other geographical areas. Brazilian artist Clarissa Tossin's suspended baskets, made in plaited arts - said to be the "humblest of crafts"25 recall Vietnamese artist Dinh Q. Lê's renowned photographic weavings, precisely because of the use of photographic paper. Plaited arts, like other 


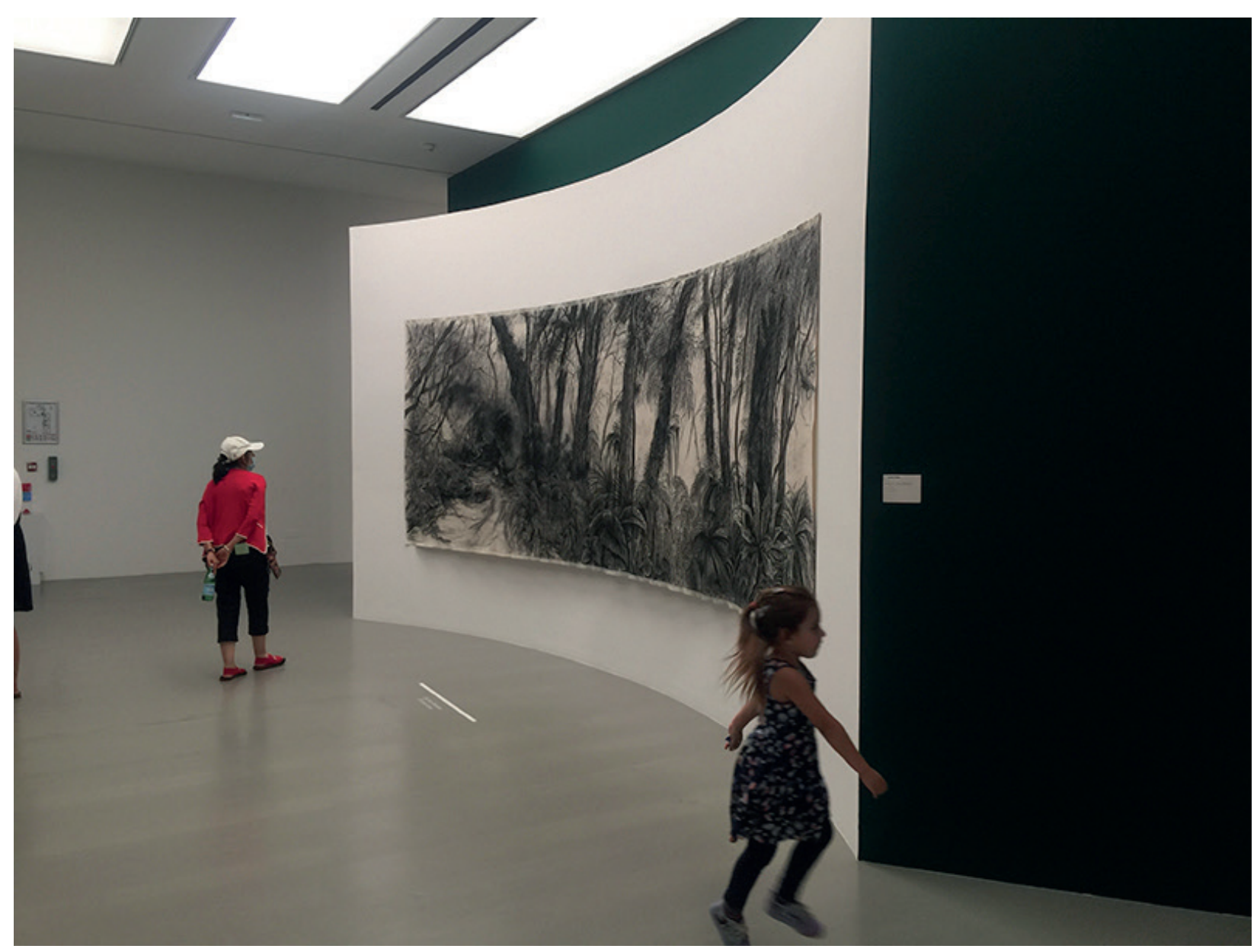

Figure 3 - Nohemí Pérez, Panorama Catatumbo (2012-16).

crafts, know no boundaries. For its width, the large-scale drawing by Colombian artist Nohemí Pérez, Panorama Catatumbo (2012-16) [Fig. 3], a cotton cloth drawn with charcoal and depicting a dense forest, recalls landscape Chinese traditional paintings on rice paper. The subject matter nature - and its depiction - the use of solely black ink on a white background - transports the viewer to large-scale paintings that Chinese artists such as Mio Pang Fei explore through his renowned experimental brush strokes. What differentiates Pérez from Mio is that her work contains a political message, relating to the excessive mining of the native lands of the forest of Catatumbo. ${ }^{26}$

The work of Brazilian artist Valeska Soares, Palimpsest (2016), depicts a global tree - the palm tree, typical of tropical destinations (some tempered climates have other species of palm trees). Made from found objects, which the artist collected, these nineteenth-century sewing boxes made in tropical and rare woods denote the continued vanishing of local trees. ${ }^{27}$ Danh Vo's piece - one which memorializes cannibalism and recalls Oswald d'Andrade's 1928 Manifesto Antropófago - recalls blue and white glazed ceramics. Most concretely, its rough imagery remembers the images of Portuguese tiles of the second part of the seventeenth-century, which equally contained several animal and human figures.

The exhibition also contains several interesting works, which in socio-political terms transport the viewer to other societies: this is the case of Mexican artist Teresa Margolles in the work Trocheras Gargando Piedras de 50kg (2019), a series of photographs depicting women transporting their own body weight in their shoulders. Looking like laborers, they call to mind the Indonesian women from the island of Bali, who work in civil construction and are frequently seen carrying heavy weights. This kind of gender equality shocks the Western viewer - one who differentiates the 


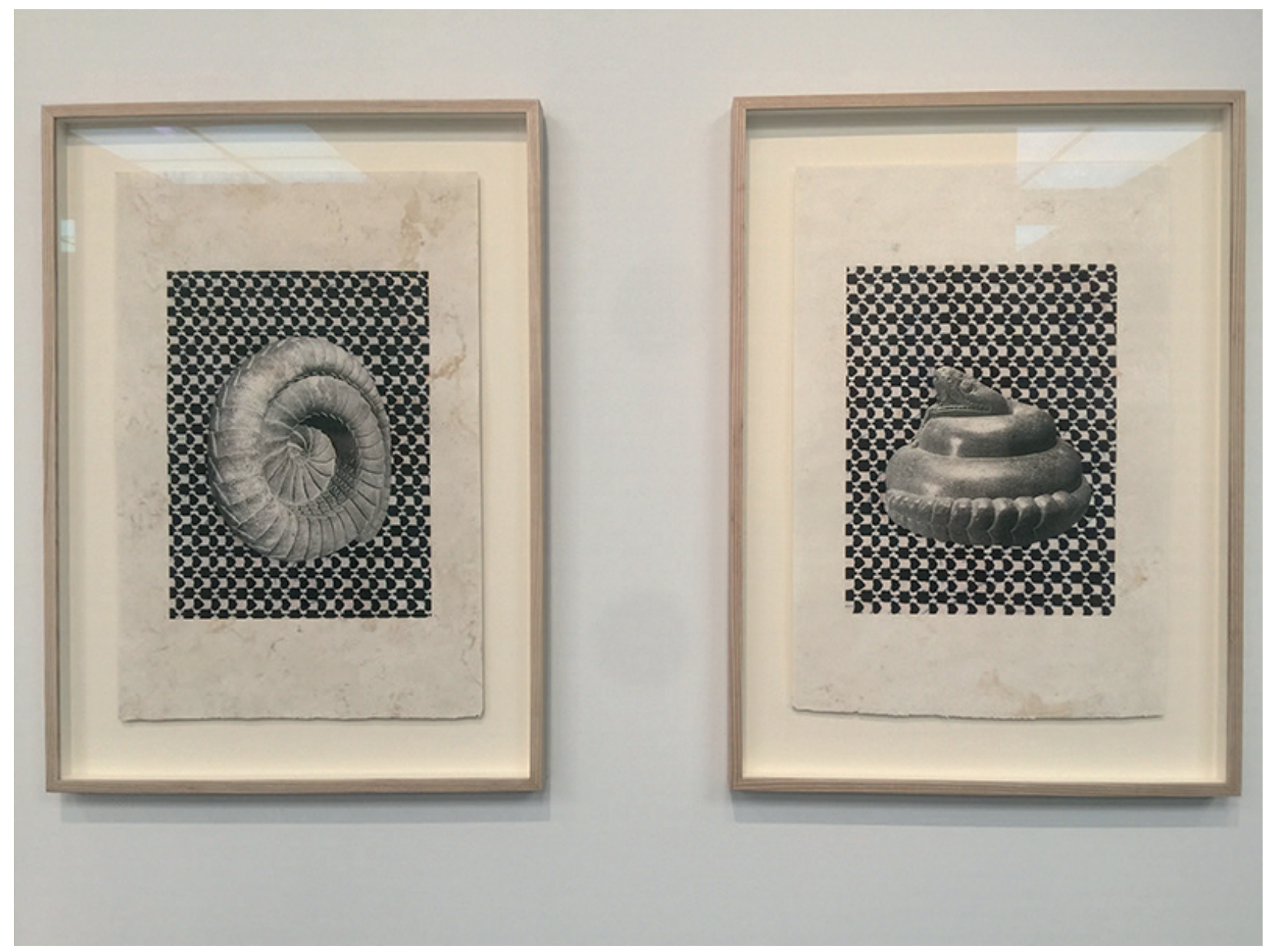

Figure 4 - Lucia Pizanni, Sagario Series (2015).

roles of each gender, while claiming equal rights and duties for women and men.

Interestingly, some other works - namely Venezuelan artist Lucia Pizzani's triptych from the Sagario Series (2015) [Fig. 4] and Peruvian Ximena Garrido-Lecca Organismos - Sistema I (2019), bring to mind the Hindu-Buddhist culture of Southeast Asia's most powerful empire to date, the Majapahit (approximately the twelfth and thirteenth centuries). Pizanni's works recalls the stone carving of this époque, which was equally highly naturalistic and heavyweight and depicted serpents, while Garrido-Lecca's installations while not anthropomorphic, contain a sexual connotation, derived from the 'phallic' and 'yonic' elements that it presents in two colors from the materials it is made of - aluminum and clay and which can be related to the Southeast Asian lingga-yoni, a symbol of unity between genders.

Many other works presented demonstrate regional sensibilities, such as Mecarõ, or spirit of the forest. In the language of the Krahô indigenous peoples, mecarõ refers to mehim; it considers men, animals, plants, rituals, the spirit of the forest (mecarõ) and the defunct as intertwined with one another. ${ }^{28}$ In this regard, the work of Brazilian Ernesto Neto, Nosso Canto (2018), is one of the most intriguing. Made to be used by visitors, it reveals Neto's vision of the artist as a shaman. Neto's crowns, tied together, support telepathic communication and advance access to a $6^{\text {th }}$ sense and parallel worlds. ${ }^{29}$

Brazilian artists Beatriz Milhazes and Maria Nepomuceno's works transport us to a color code and a materiality that is specifically Brazilian. While Milhazes's works derived from her conceptual art period can be regarded as decorative, ${ }^{30}$ [Fig. 5] Nepomuceno's are antiform and born form encounters with native communities with which the artist exchanges crafting methods. ${ }^{31}$

Finally, the neo-concrete group, specifically Lygia Clark and Ivan Serpa. Clarks' Bicho Caranguejo (1960s) were a turning point in her 


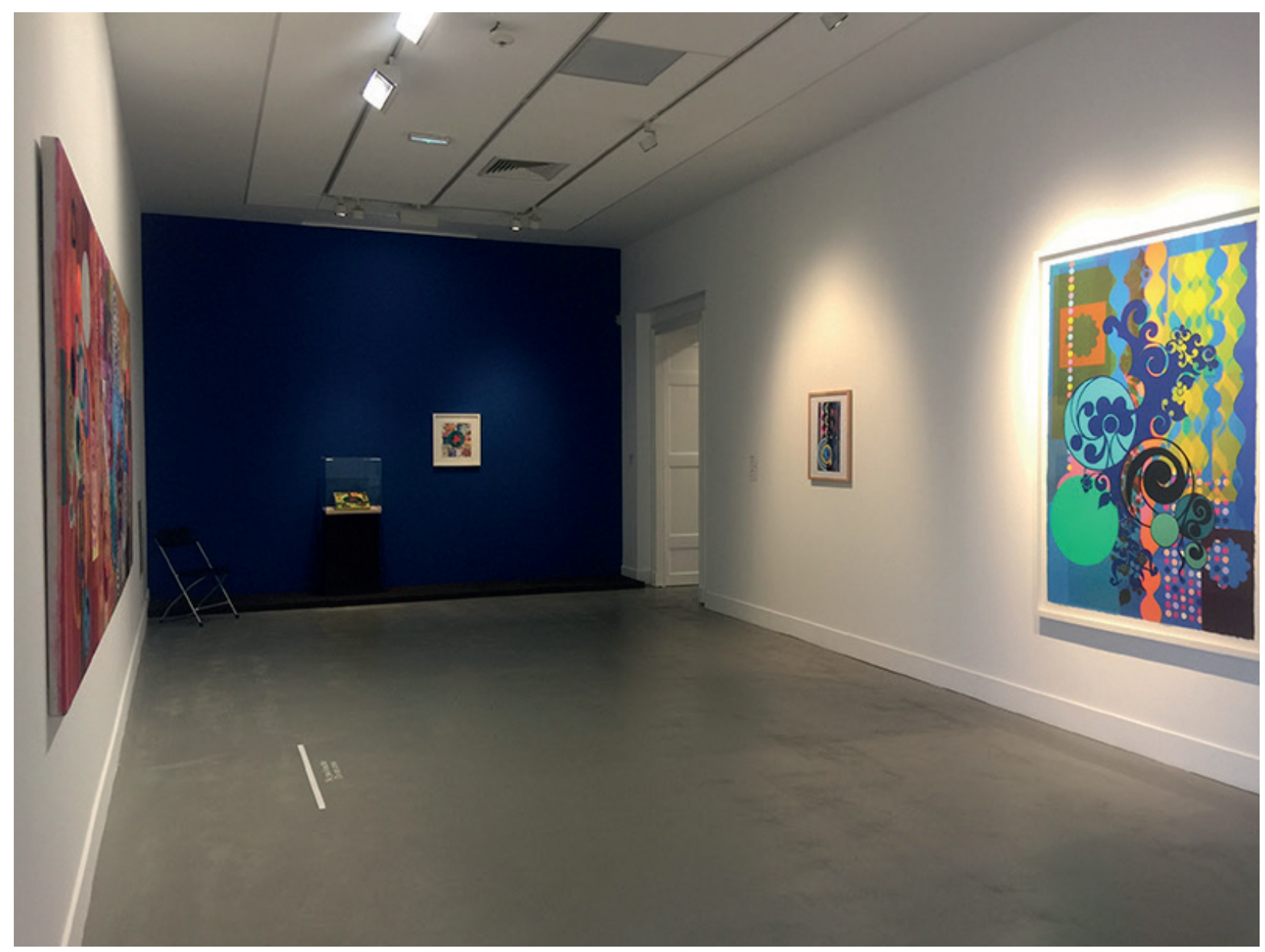

Figure 5 - A view of Beatriz Milhazes room.

career, instigating her to start procuring modes of expression beyond the visual. Serpa's minimal representations entitled Série Amazônica (1970) constitute a synthesis of the natural world through movements such as Tropicália, that emerged at this time.

Brazilian artist Anna Bella Geiger's História de Brazil: Little Boys and Girls I, II and III (1975) was chosen to market the show. This was an effective method to attract audiences, because the superposition of the images of Native Indians onto the eyes of an urban and sophisticated woman transmit the notion of regard of the other through the popular notion that 'the eyes are the window to the soul'. [Fig. 6] It equally suggests the urgency in knowing coexistent worlds, that hardly touch each other but live in coeval coexistence.

The Mecarõ exhibition, the third in Bourriaud's project at the MO.CO., also reminds the Third Havana Biennale, Tradition and Contemporaneity, curated by Gerardo Mosquera. Its program is focused, down to earth, and its message is highly visible: the Amazon basin must be regarded as an essential part of life, and as a source of riches beyond those that are exploitable through mining and massive deforestation.

Each work was given room to 'breathe', space to be contemplated; there is enough room to profit from the numerous sensorial pieces. Moreover, the staff was readily prepared to explain any aspects one might want to know further. Unlike the work of Equatorian artist Manuela Ribadaneira I Asked Directions for Getting Lost (2012) suggests as the forest's experience, in this exhibition one navigates the space in quiet contemplation, while sensing Petitgas's aforementioned underlying tension.

The materials provided - namely the 40-page booklet and the 184-page publication - are aimed at aiding the audience to journey the exhibition on the one hand, and to learn more about the prejudice that remains perpetuated on 

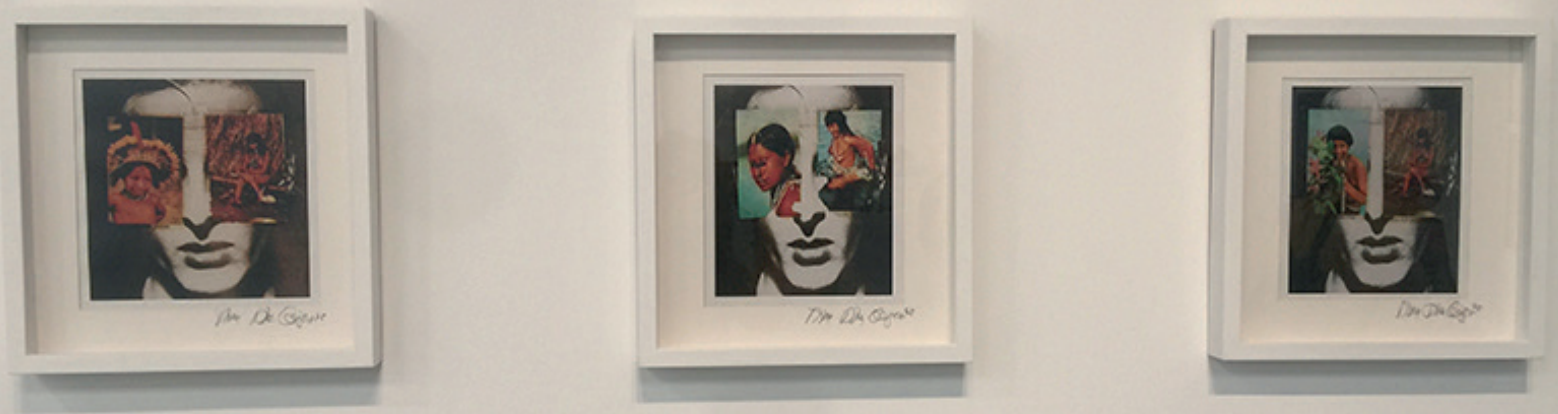

Figure 6 - Anna Bella Geiger, História do Brazil: Little Boys and Girls (1975).

the subject of the Amazon, on the other hand. Together, alongside with works, they provide the visitor with a complete experience and a muchneeded multimedia information on the 'lungs of the Planet'.

NOTE: This work is financed by national funds through the FCT - Foundation for Science and Technology, I.P., under the project CEECIND/01949/2018.

\section{NOTES}

1. "MO.CO.Montepellier Contemporain," MO.CO. Montepellier Contemporain, 2019, https://www. moco.art/en/home-page.

2. See, Boaventura de Sousa Santos, "As Estátuas Do Nosso Descontentamento," June 18, 2020, https:// www.sul21.com.br/opiniaopublica/2020/06/ as-estatuas-do-nosso-descontentamento-porboaventura-de-sousa-santos/.

\section{3. "MO.CO."}

4. Catherine Petitgas quoting "her hero Marcel Duchamp". See, Anne Kerekes, "Interview with Catherine Petitgas," in Mecarõ: Amazonia in the Petitgas Collection, Montpellier Contemporain: One Institution, Three Sites 3 (Milano: Silvana Editoriale, 2020), 41.

5. Kerekes, 40.

6. Kerekes, 40.

7. Kerekes, 39.

8. Kerekes, 39.

9. Kerekes, 40.

10. Catherine Petitgas received a diploma in Modern Art Studies from Chistie's and a Master's degree in the History of Modern Art from the Courtauld Institute in London. See Kerekes, 39.

11. Kerekes, 38. 
12. Kerekes, 39.

13. Nicolas Bourriaud, "Introduction," in Mecarõ, 8-9.

14. Kerekes, "Interview with Catherine Petitgas," 40.

15. Kerekes, 41.

16. Mecarõ: L'Amazonie dans la Collection Petitgas, 06.03.2020 > 31.05.2020 (Montpellier: MO.CO.Montpellier Contemporain, 2020), 7.

17. Kerekes, "Interview with Catherine Petitgas," 42.

18. Kerekes, 40-41.

19. Kiki Mazzucchelli, "A Partial Account of Contemporary Art in the Amazon Basin," in Mecarõ, 21.

20. Mazzucchelli, 21.

21. Bourriaud, "Mecarõ," 8.

22. Mazzucchelli, "A Partial Account of Contemporary Art in the Amazon Basin," 22.

23. Montien Boonma interview: Arte Amazonas (1992), interview by Alfred Pawlin and Montien Boonma, August 6, 2010, https://www. artdesigncafe.com/montien-boonma-interview1992?fbclid=IwAR3AzpaTgERUjSYGzZmENbFgGJ cNe7dGLwbR1qVU38hrGnZQ57rO2Frv3xE.

24. Kerekes and Kok, eds., "Chelpa Ferro: Jungle Jam," in Mecarõ, 71.

25. Bernard Sellato, "Art and Identity in the Plaited Arts of Borneo: An Introduction," in Plaited Arts from the Borneo Rainforest, ed. Bernard Sellato (Honolulu: University of Hawai'i Press, 2012), 4.

26. Kerekes and Kok, eds., "Nohemí Pérez: Panorama Catatumbo," in Mecarõ, 126-27.

27. Kerekes and Kok, eds., "Valeska Soares: Palimpsest," in Mecarõ, 134-35.

28. "MO.CO.," 7.

29. Kerekes and Kok, eds., "Ernesto Neto: Nosso Canto," in Mecarõ, 112.

30. Kerekes and Kok, eds., "Beatriz Milhazes: Férias de Verão," in Mecarõ, 106-7.
31. Kerekes and Kok, eds., "Maria Nepomuceno: Untitled," in Mecarõ, 110-11.

\section{SOBRE A AUTORA}

Leonor Veiga é historiadora de arte, atualmente associada à Universidade de Lisboa através do projeto "A History of Presence: a dialogue between Portuguese collections of material culture from Southeast Asia and Southeast Asian artists". A sua dissertação de doutoramento, intitulada The Third Avant-Garde: Contemporary Art from Southeast Asia Recalling Tradition (Leiden University, 2018) foi vencedora do Prémio 'Melhor Dissertação em Humanidades' pela International Convention of Asian Scholars (2019). A sua escrita nas artes (2010-2021) foca maioritariamente o Sudeste Asiático e arte não-ocidental, e o seu trabalho curatorial (2006-20) inclui exposições na Indonésia, Moçambique, Londres, Macau e Lisboa.

Leonor Veiga is an art historian, currently associated with the University of Lisbon through the project "A History of Presence: a dialogue between Portuguese collections of material culture from Southeast Asia and Southeast Asian artists". Her Ph.D. dissertation, entitled The Third Avant-Garde: Contemporary Art from Southeast Asia Recalling Tradition (Leiden University, 2018) was awarded the 'Humanities Best Dissertation' Prize by the International Convention of Asian Scholars (2019). Her writing on the arts (20102021) focuses mainly on Southeast Asia and nonWestern art, and her curatorial work (2006-20) includes exhibitions in Indonesia, Mozambique, London, Macau and Lisbon. 